\title{
Pelaksanaan monitoring, controlling, surveillance kapal pengangkut ikan di atas 30 GT di Pelabuhan Perikanan Samudera Bitung
}

Implementation monitoring, controlling, surveillance on fish transport vessels above 30 GT in oceanic fishery harbor Bitung

APriliLian. E. SUPIT*, REVOLS. D. CH. PAMIKIRAN dan FrANSISCO. P.T. PANGALILA

Program Studi Pemanfaatan Sumberdaya Perikanan, Fakultas Perikanan dan Ilmu Kelautan, Universitas Sam Ratulangi

\begin{abstract}
The Directorate General of Marine Resources and Fisheries through the Marine and Fisheries Resources Supervision Base Bitung charge of making sure that the departure of fishing boats and catch landing in the Oceanic Fishing Port Bitung as their port corresponding Indonesia $n$ Law. This research aimed at monitoring the compliance of fishing vessels and also against illegal activities that violate laws and regulations in force and also to the application of sanctions against the ships as a consequence of the violation. This research was conducted by descriptive method. Penalties for violations carried out by the legislation in force, namely the technical manual operational control of fishing boats no Kep.143 / DJ.PSDKP / 2012. The results showed that the percentage of degree of compliance with the rules on a high compliance rate $(76 \%-100 \%)$, where the rules are implemented, namely the suitability of the base port, the suitability of the ship documents, the number of operation days and suitability of the number of fish with the storage capacity. The application of sanctions has been committed against non-compliant ships, and it has shown a good effect for the fishery based in Port of Bitung Ocean Fisheries.
\end{abstract}

Key words : fish transport vessels, surveillance, compliance

\begin{abstract}
ABSTRAK
Direktorat Jenderal Pengawasan Sumberdaya Kelautan dan Perikanan melalui Pangkalan Pengawasan Sumberdaya Kelautan dan Perikanan Bitung bertugas memastikan kegiatan kapal perikanan yang pemberangkatan dan pendaratannya di Pelabuhan Perikanan Samudera Bitung sebagai pelabuhan pangkalan sesuai peraturan perundangundangan yang berlaku di Indonesia. Penelitian lebih ditujukan pada pengawasan terhadap kepatuhan kapal perikanan dan juga terhadap kegiatan-kegiatan illegal yang menyalahi peraturan perundang-undangan yang berlaku, dan juga penerapan sanksi terhadap kapal-kapal tersebut sebagai konsekuensi atas pelanggaran yang dilakukan. Penelitian ini dilakukan berdasarkan metode deskriptif. Sanksi terhadap pelanggaran dilakukan berdasarkan pada peraturan perundang-undangan yang berlaku yaitu petunjuk teknis pengawasan operasional kapal perikanan no Kep.143/DJ.PSDKP/2012. Hasil penelitian menunjukkan bahwa persentase tingkat kepatuhan terhadap aturan, berada pada tingkat kepatuhan yang tinggi (76\%-100\%), dimana aturan yang dilaksanakan yaitu kesesuaian pelabuhan pangkalan, kesesuaian dokumen kapal, jumlah hari operasi dan kesesuaian jumlah ikan dengan kapasitas penyimpanan. Penerapan sanksi telah dilakukan terhadap kapal yang tidak patuh, dan hal ini telah menunjukkan efek yang baik bagi pelaku perikanan yang berpangkalan di Pelabuhan Perikanan Samudera Bitung.
\end{abstract}

Kata -kata kunci : kapal pengangkut ikan, pengawasan, kepatuhan.

\section{PENDAHULUAN}

\section{Latar belakang}

Indonesia sebagai sebuah negara kepulauan yang sebagian besar wilayahnya terdiri dari laut, memiliki potensi perikanan yang sangat besar dan beragam. Dalam pembangunan perikanan yang perlu mendapatkan perhatian dari semua pihak, baik pemerintah, masyarakat maupun pihak lain

\footnotetext{
*Penulis untuk penyuratan; email: supitapril@gmail.com
} 
adalah adanya gejala penangkapan ikan yang berlebih, pencurian ikan, dan tindakan illegal fishing yang tidak hanya menimbulkan kerugian bagi negara, tetapi juga mengancam kepentingan nelayan dan pembudidaya ikan, iklim industri, dan usaha perikanan nasional. Permasalahan tersebut harus diselesaikan dengan sungguhsungguh, sehingga penegakan hukum di bidang perikanan menjadi sangat penting dan strategis dalam rangka menunjang pembangunan perikanan secara terkendali dan berkelanjutan. Dengan di imbangi upaya pengawasan pemanfaatan sumber daya perikanan untuk menjaga kelestarian sumber daya kelautan dan perikanan, mengamankan usaha perikanan serta melindungi keberlanjutan mata pencaharian masyarakat perikanan. Direktorat Jenderal Pengawasan Sumberdaya Kelautan dan Perikanan melalui Pangkalan Pengawasan Sumberdaya Kelautan dan Perikanan Bitung bertugas memastikan kegiatan kapal perikanan yang pemberangkatan dan pendaratannya di Pelabuhan Perikanan Samudera Bitung sebagai pelabuhan pangkalannya sesuai peraturan perundang-undangan yang berlaku di Indonesia.

\section{Tujuan penelitian}

Menganalisis terjadinya tindakan-tindakan yang berkaitan dengan kegiatan illegal fishing kapal pengangkut ikan di atas $30 \mathrm{GT}$, khususnya dalam hal tingkat kepatuhan terhadap peraturan perundang-undangan yang berlaku dan mengetahui sejauh mana penegakan hukum melalui sanksi atau hukuman yang diberlakukan.

\section{Tempat dan waktu penelitian}

Penelitian ini dilakukan di Pelabuhan Perikanan Samudera Bitung khususnya Pangkalan Pengawasan Sumberdaya Kelautan dan Perikanan Bitung. Waktu pelaksanaan berlangsung dari bulan Mei 2014 - Oktober 2014.

\section{METODE PENELITIAN}

Penelitian ini dilakukan dengan metode deskriptif yang didasarkan pada studi kasus (Ariyanto, 1986). Data yang di kumpulkan adalah data sekunder dari kegiatan kapal pengangkut ikan dengan kapasitas kapal di atas 30 Gross Ton (GT) di Pelabuhan Perikanan Samudera Bitung. Data jumlah kapal berdasarkan kategori kapasitas kapal dan bulan pengamatan disajikan pada tabel 1 .

Tabel 1. Jumlah Kapal Berdasarkan GT dan bulan pengamatan.

\begin{tabular}{|c|c|c|c|c|c|c|c|c|}
\hline \multirow{2}{*}{ No } & \multirow{2}{*}{$\begin{array}{c}\text { Ukuran } \\
\text { Kapal } \\
\text { (GT) }\end{array}$} & \multicolumn{6}{|c|}{ Jumlah Kapal } & \multirow{2}{*}{$\begin{array}{c}\text { Jumlah } \\
\text { Rata- } \\
\text { Rata }\end{array}$} \\
\hline & & Mei & Juni & Juli & Agustus & September & Oktober & \\
\hline 1 & $30-100$ & 37 & 53 & 55 & 87 & 71 & 52 & 355 \\
\hline 2 & $101-171$ & 33 & 38 & 35 & 39 & 32 & 25 & 202 \\
\hline 3 & $>171$ & 8 & 1 & 4 & 3 & 2 & 5 & 23 \\
\hline & Total & 78 & 92 & 94 & 129 & 105 & 82 & 580 \\
\hline
\end{tabular}

Variabel kepatuhan dari kegiatan kapal pengangkut ikan ditentukan berdasarkan Juknis Ditjen PSDKP no 143 Tahun 2012 yaitu : kesesuaian pelabuhan pangkalan, kesesuaian dokumen kapal, hari operasi, dan kesesuaian jumlah ikan dengan kapasitas penyimpanan di kapal pengangkut ikan.

\section{Metode Analisis Data}

Tingkat kepatuhan kapal pengangkut ikan pada berbagai kategori dan waktu pengamatan dianalisis berdasarkan rumusan yang dikemukakan oleh
Surakhmad (1990) dan telah disesuaikan sebagai berikut :

$$
\mathrm{P}=\frac{\mathrm{n}}{\mathrm{N}} \times 100 \%
$$

Keterangan :

$\mathrm{P}$ : Persentase kepatuhan terhadap aturan

$\mathrm{n}$ : Jumlah realita kepatuhan kapal pengangkut

$\mathrm{N}$ : Jumlah Seluruh kapal pengangkut dalam kategori pengamatan. 
Klasifikasi tingkat kepatuhan kapal pengangkut ikan berkapasitas di atas 30 GT, menggunakan skala penilaian oleh Riduwan (2007) yaitu :

$$
\begin{aligned}
76 \%-100 \% & =\text { Tinggi } \\
51 \%-75 \% & =\text { Cukup Patuh } \\
26 \%-50 \% & =\text { Kurang Patuh } \\
0 \%-25 \% & =\text { Rendah }
\end{aligned}
$$

\section{HASIL DAN PEMBAHASAN}

Tingkat kepatuhan terhadap peraturan perundangundangan
Kepatuhan kapal pengangkut berukuran di atas 30 GT yang berpangkalan di Pelabuhan Perikanan Samudera Bitung terhadap aturan-aturan yang ada dibagi dalam tiga kategori yaitu 30-100 GT, 101170 GT dan lebih besar dari 171 GT. Hasil analisis tingkat kepatuhan terhadap aturan berdasarkan Juknis Ditjen PSDKP no 143 Tahun 2012 yang meliputi : kesesuaian pelabuhan pangkalan, kelengkapan dokumen kapal, hari operasi pengangkutan ikan, dan kesesuaian jumlah ikan dengan kapasitas penyimpanan ikan disajikan pada tabel 2, 3, dan 4, dan pada gambar 1, 2, dan 3 .

Tabel 2. Persentase kepatuhan terhadap aturan dari kapal pengangkut ikan 30 - 100 GT, periode Mei-Oktober 2014

\begin{tabular}{|l|r|r|r|r|r|c|}
\hline \multirow{2}{*}{ Uraian Aturan } & \multicolumn{7}{c|}{ Persentase Kepatuhan (\%) } \\
\cline { 2 - 7 } & \multicolumn{1}{|c|}{ Mei } & \multicolumn{1}{c|}{ Juni } & \multicolumn{1}{c|}{ Juli } & \multicolumn{1}{c|}{ Agustus } & September & Oktober \\
\hline Kesesuaian Pelabuhan Pangkalan & 99.97 & 88.67 & 96.36 & 86.20 & 92.95 & 96.15 \\
\hline Kesesuaian Dokumen Kapal & 100.00 & 100.00 & 100.00 & 100.00 & 100.00 & 100.00 \\
\hline Hari Operasi & 86.48 & 77.35 & 81.81 & 77.01 & 91.54 & 92.30 \\
\hline $\begin{array}{l}\text { Kesesuaian Jumlah Ikan dengan } \\
\text { Kapasitas Penyimpanan }\end{array}$ & 94.59 & 98.11 & 100.00 & 95.40 & 100.00 & 96.15 \\
\hline
\end{tabular}

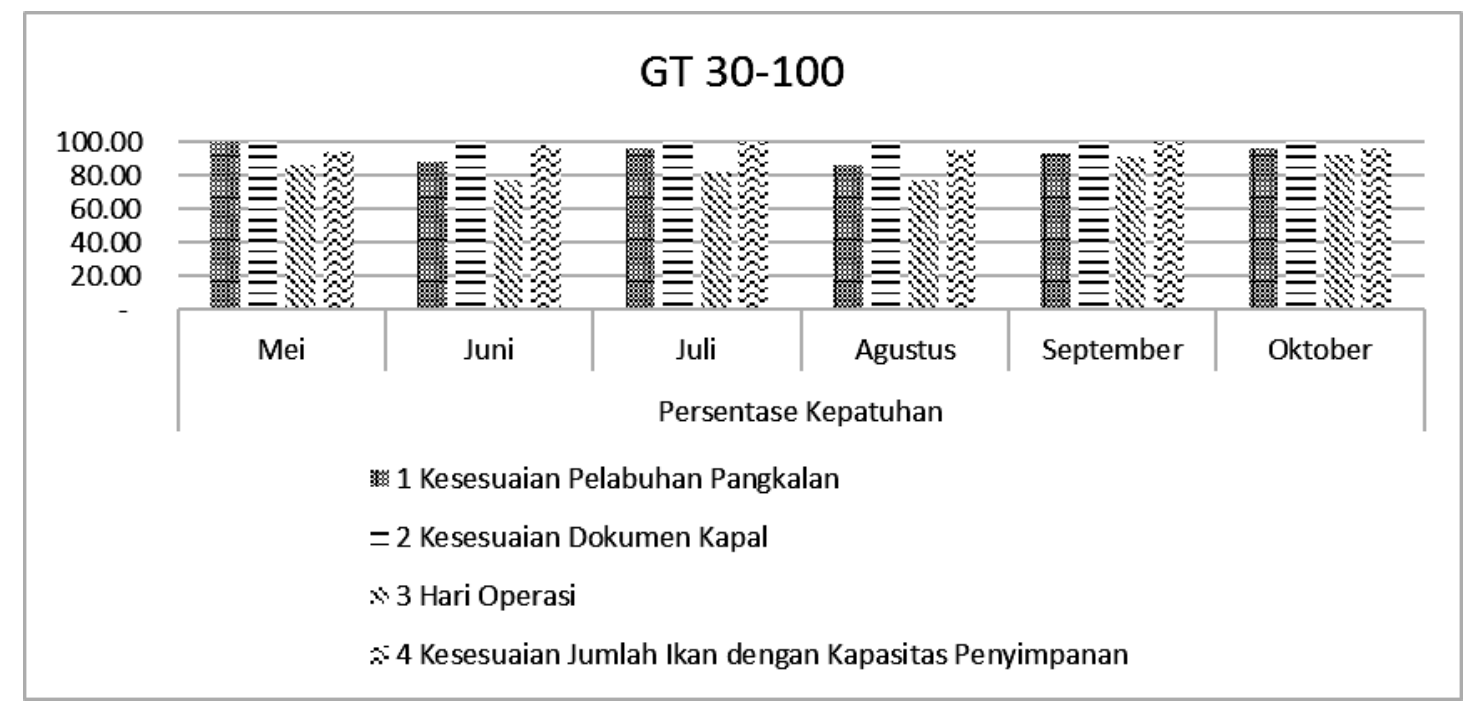

Gambar 1. Grafik persentase kepatuhan terhadap aturan dari kapal pengangkut ikan 30-100 GT, periode Mei-Oktober 2014

Berdasarkan tabel $(2,3$, dan 4) dan gambar $(1,2$ dan 3) dapat dilihat bahwa persentase kepatuhan kapal pengangkut diatas 30 GT yang berpangkalan di Pelabuhan Perikanan Samudera Bitung berada pada tingkat kepatuhan yang baik. Dari keempat kategori pelanggaran dapat dilihat bahwa kategori paling banyak di langgar adalah seringnya para pelaku, nakhoda ataupun pemilik yang tidak mendaratkan hasil tangkapan/angkutannya di setiap pelabuhan pangkalan yang sudah ditentukan dalam Surat Ijin Kapal Pengangkut Ikan (SIKPI), dan lamanya hari operasi yang di tentukan dari keberangkatan awalnya sampai kapal pengangkut ini kembali ke pelabuhan pangkalannya. Jika 
dilihat dari tingkat kepatuhan, ada dua kategori yang memberikan nilai yang sangat baik (tinggi) yaitu kategori kesesuaian dokumen kapal pengangkut dan kesesuaian jumlah ikan dengan kapasitas penyimpanan kapal pengangkut tersebut.Hal ini memberikan pengertian bahwa nakhoda, agen kapal maupun pemilik kapal sudah berusaha dengan baik memenuhi persyaratan administrasi dari kapal pengangkut ikan di atas 30 GT untuk taat terhadap aturan yang berlaku di negara Indonesia, khususnya di Pelabuhan Perikanan Samudera Bitung.

\section{Penegakan Hukum Terhadap Tindakan Illegal Fishing}

Melalui petunjuk teknis operasional pengawasan kapal perikanan no. Kep.143/DJ.PSDKP/2012 (Anonimous, 2012) memberikan efek kepada setiap pemilik kapal, nakhoda kapal ikan dan agen kapal ikan untuk jera terhadap illegal fishing yang antara lain mendaratkan hasil angkutan tidak sesuai dengan pelabuhan pangkalan yang tertera di SIKPI (Surat Ijin Kapal Pengangkut Ikan), jeda waktu yang lama diatas 30 hari yang memberikan waktu bagi nakhoda kapal untuk melakukan transhipment baik dari kapal ke luar negeri maupun ke kapal pengangkut illegal, dokumen kapal illegal dan ikan hasil tangkapan yang diangkut tidak sesuai dengan jumlah hari operasi maupun kapasitas kapal (GT). Tindak pidana yang di berikan kepada pemilik kapal maupun nakhoda kapal yang melakukan illegal fishing yaitu berupa penghentian izin pengoperasian kapal pengangkut ikan, untuk memberikan efek jera kepada mereka yang melakukan pelanggaran lagi.

Tabel 3. Persentase kepatuhan terhadap aturan dari kapal pengangkut ikan 101-171 GT, periode Mei-Oktober 2014

\begin{tabular}{|c|l|r|r|r|r|r|c|}
\hline \multirow{2}{*}{ No } & \multicolumn{1}{|c|}{ Uraian Aturan } & \multicolumn{6}{c|}{ Persentase Kepatuhan (\%) } \\
\cline { 2 - 8 } 1 & $\begin{array}{l}\text { Kesesuaian Pelabuhan } \\
\text { Pangkalan }\end{array}$ & 96.96 & 100.00 & 94.28 & 97.43 & 93.75 & 100.00 \\
\hline 2 & Kesesuaian Dokumen Kapal & 100.00 & 100.00 & 100.00 & 100.00 & 100.00 & 100.00 \\
\hline 3 & Hari Operasi & 96.96 & 100.00 & 100.00 & 97.43 & 100.00 & 84.00 \\
\hline 4 & $\begin{array}{l}\text { Kesesuaian Jumlah Ikan } \\
\text { dengan Kapasitas } \\
\text { Penyimpanan }\end{array}$ & & 74.28 & 82.05 & 96.87 & 80.00 \\
\hline
\end{tabular}

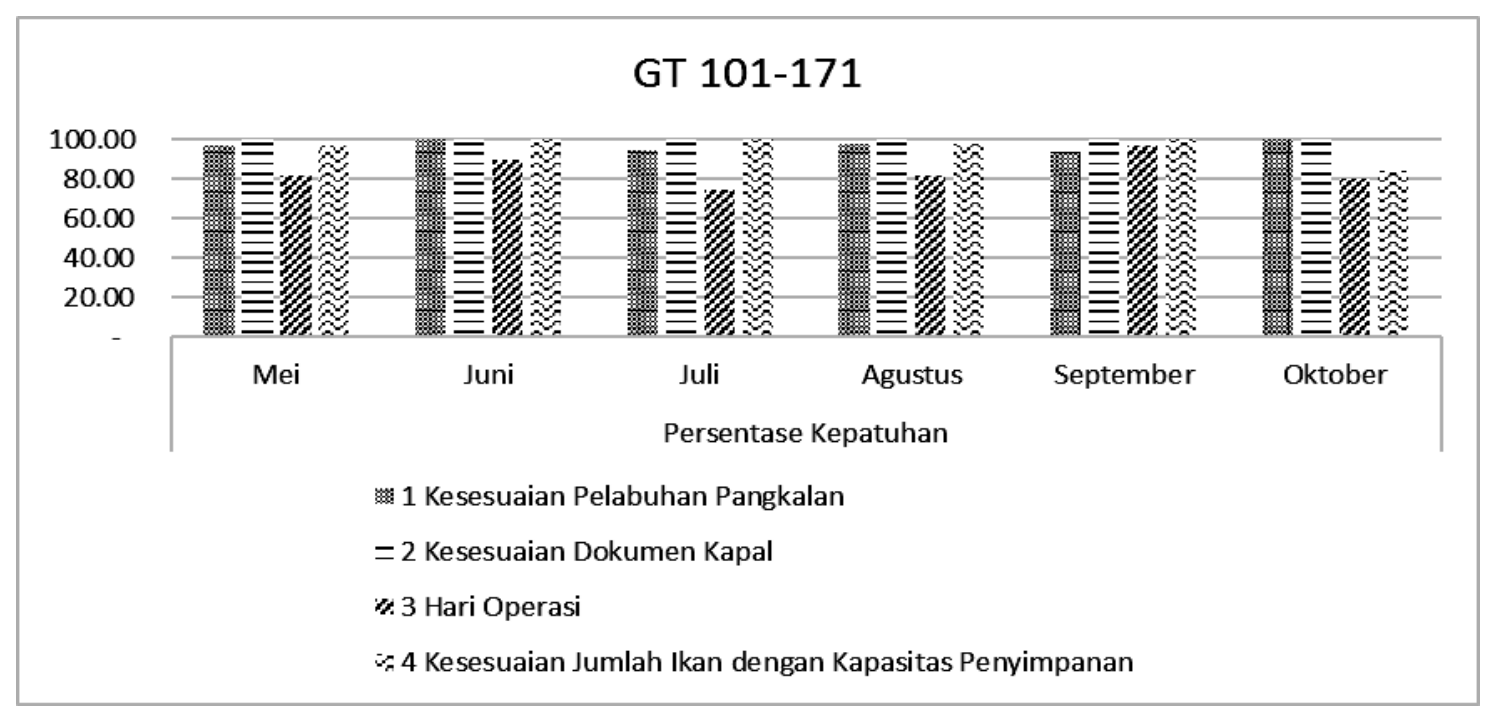

Gambar 2. Grafik persentase kepatuhan terhadap aturan dari kapal pengangkut ikan 101-171 GT, periode Mei-Oktober 2014 
Tabel 4. Persentase kepatuhan terhadap aturan dari kapal pengangkut ikan > 171 GT, periode Mei-Oktober 2014

\begin{tabular}{|c|l|r|r|r|r|r|r|}
\hline \multirow{2}{*}{ No } & \multicolumn{1}{|c|}{ Uraian Aturan } & \multicolumn{6}{|c|}{ Persentase Kepatuhan (\%) } \\
\cline { 3 - 8 } 1 & \multicolumn{1}{c|}{ Mei } & \multicolumn{1}{c|}{ Juni } & \multicolumn{1}{c|}{ Juli } & \multicolumn{1}{c|}{ Agustus } & September & Oktober \\
\hline & $\begin{array}{l}\text { Kesesuaian pelabuhan } \\
\text { pangkalan }\end{array}$ & 62.50 & 62.50 & 57.14 & 100.00 & 100.00 & 100.00 \\
\hline 3 & $\begin{array}{l}\text { Kesesuaian dokumen } \\
\text { kapal }\end{array}$ & 100.00 & 100.00 & 100.00 & 100.00 & 100.00 & 100.00 \\
\hline 4 & 75.00 & 100.00 & 71.42 & 66.67 & 50.00 & 80.00 \\
\hline & $\begin{array}{l}\text { Kesesuaian jumlah } \\
\text { ikan dengan kapasitas } \\
\text { penyimpanan }\end{array}$ & 100.00 & 100.00 & 100.00 & 100.00 & 100.00 & 80.00 \\
\hline
\end{tabular}

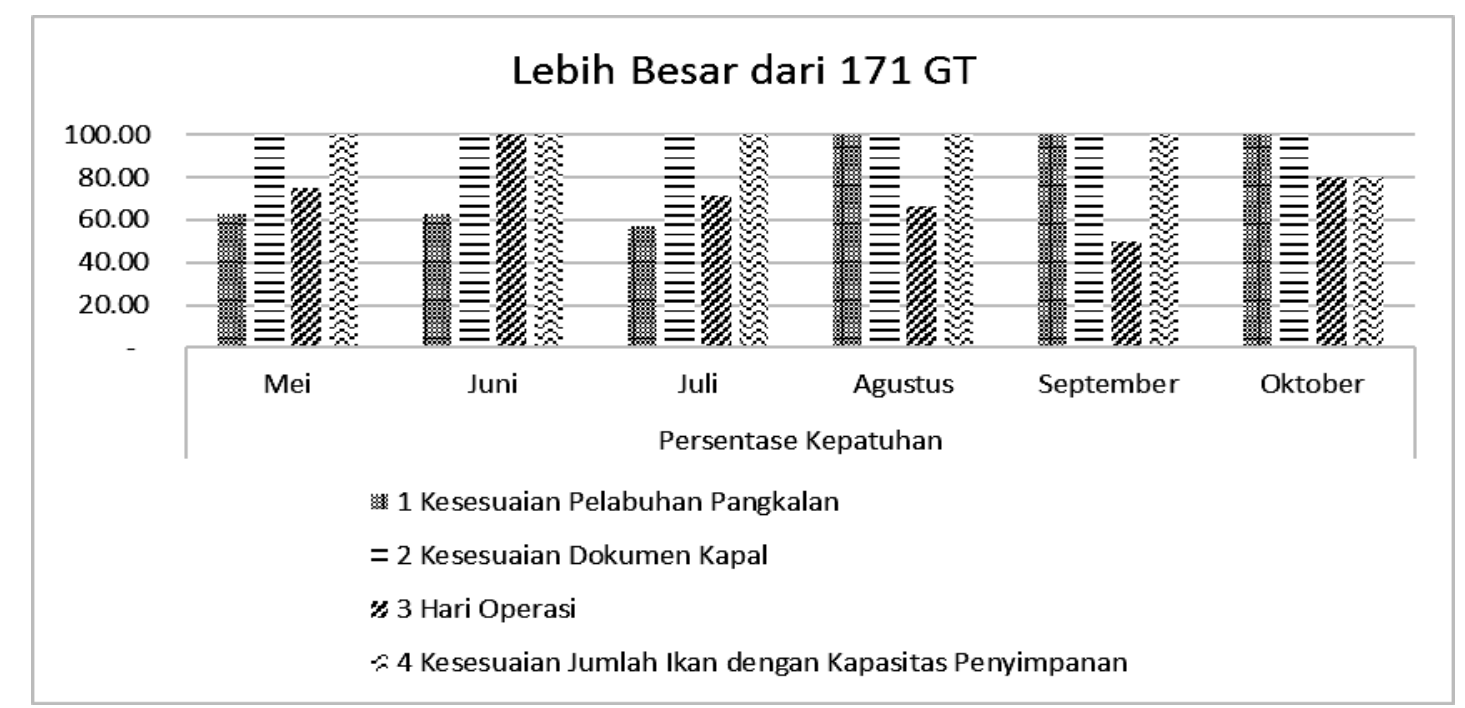

Gambar 3. Grafik persentase kepatuhan terhadap aturan dari kapal pengangkut ikan >171 GT, periode Mei-Oktober 2014

\section{Kesimpulan}

Kepatuhan kapal pengangkut ikan di atas 30 GT tergolong baik dengan capaian nilai $76 \%-100 \%$, hal ini mengartikan bahwa kesadaran nelayan dan pemilik kapal untuk mentaati peraturan perundang-undangan tentang pengoperasian kapal pengangkut ikan secara umum sudah baik ; walaupun dari aturan kesesuaian pelabuhan pangkalan dan lamanya hari operasi masih terdapat ketidak-patuhan.

Sanksi yang diberikan oleh pengawas perikanan Pangkalan Pengawasan Sumberdaya Kelautan dan Perikanan Bitung atas pelanggaran yang di lakukan yaitu penghentian/pembekuan ijin pengoperasian kapal pengangkut ikan diatas 30 GT, menjadi salah satu tindakan untuk meredam tindakan illegal fishing yang dilakukan oleh pelaku perikanan yang berpangkalan di Pelabuhan Perikanan Samudera Bitung.

\section{Daftar Pustaka}

Anonimous. (2012). Surat Keputusan Nomor : KEP.143/DJPSDKP/2012 tentang Petunjuk Teknis Operasional Pengawasan Kapal Perikanan. Jakarta: Direktur Jenderal Pengawasan Sumber Daya Kelautan dan Perikanan.

Ariyanto. (1986). Prosedur Penelitian Suatu Pendekatan Praktis. Bina Aksara.

Riduwan. (2007). Skala Pengukuran Variabel-Variabel penelitian. . Bandung : Alfabeta.

Surakhmad, W. (1990). Pengantar Penelitian Ilmiah: Dasar, Metode dan Tekhnik. Bandung: Penerbit Tarsito. 